\title{
A semiotic analysis of political cartoons on the first 100 days of Anies Baswedan government
}

\author{
1Nindya Hasanah, ${ }^{1}$ Didin Nuruddin Hidayat* \\ ${ }^{1}$ Universitas Islam Negeri Syarif Hidayatullah Jakarta, Indonesia
}

*Corresponding Author

Email: didin.nuruddin@uinjkt.ac.id

\begin{abstract}
Nowadays, information can be conveyed not only through words, but also through images. An image is also a form of one-way communication because, through an image, people can convey the meaning. This study aimed to describe Anies Baswedan's political cartoons on his first 100 days as a governor. This study employed a qualitative research approach, and the content or document analysis as the research design. The researchers collected and analyzed the data dealing with the relationship between the utterances and Anies' cartoons on his first 100 days as Jakarta's governor. In analyzing the data, some steps were taken: first, categorizing the sign into icon, symbol, index using a typology of signs; second, interpreting the meaning of the political cartoons; last, drawing conclusions based on the result of the analysis. The study found that the signs in those political cartoons had powerful meanings to convey the aspiration of Indonesian people freely towards Anies' government. Also, the fact that the cartoons were in the forms of images eased the readers in understanding the meanings behind them, and the political cartoons deal with the relationship between visual and verbal signs of cartoons because it will be helpful for the researchers to know about events depicted in those cartoons. The study also offers some potential use of cartoons for language teaching, even though the challenges of employing them are evident.
\end{abstract}

Keywords: Anies Baswedan; linguistics; political cartoons; semiotic analysis

Received:

Revised:

Accepted:

Published:

31 May 2020

18 July 2020

25 July 2020

31 August 2020

\section{INTRODUCTION}

In the modern era, media develop rapidly. People can use media for communicating with each other and obtaining some information happening in the society. Richmond and McCroskey (2019) argued that the importance of communication in human society had been recognized for thousands of years, far longer than we can demonstrate through recorded history. It shows that communication already existed from thousands of years ago for the survival of human life. Communication can be distinguished into two kinds. The first kind is the dialogue between two people or more and give feedback to each other's utterance, for example, by telephone or daily conversation. In contrast, 
Hasanah, N., \& Hidayat, D.N. (2020). A semiotic analysis of political cartoons on the first 100 days of Anies Baswedan government. EduLite: Journal of English Education, Literature, and Culture, 5 (2), 322333. DOI: http://dx.doi.org/10.30659/e.5.2.322-333

the second kind is communication by seeing, hearing the voice from the sender information, and we cannot give feedback to each other, for example, radio broadcast, television broadcast, and information on the internet.

Nowadays, the information is delivered not only through words, but also through images. An image is also a form of one-way communication because, through an image, people can convey the meaning. In our daily life, we are familiar with many forms of signs, such as pictures, banners, cartoons that we usually found in the media. By the media, we can get all of the information happening in the society. For the delivering news not only can be done in words, but it could be by cartoons. Cartoons are used by many people to make news more communicative and attractive for the readers.

A political cartoon appears on the media to emphasize the point of view or ideas through the use of illustration. Moreover, the cartoon is often exaggerated that it has entertaining as well as informative content. They are made by the artist that can also be satirical or even serious. In particular the cartoons were present, as cartoonists paid their colleagues a direct tribute and ignited an emotions from the peoples. Straightforward, effortless actions such as content appreciating and sharing 1 have become substantial as cartoon sharing or slogan posting (Marin-Arrese, 2019).

The existence of political cartoon could be able to connect the current issues with people in an easy to understand manner. Mondry (2017) asserted "the power of the political cartoon lies not in the specific artist's intent or success at fostering change but in the degree to which, and how, the cartoonist taps the collective consciousness of readers (p. 79)". It means that the purpose of political cartoons is merely to deliver the view of cartoonists about a specific topic or current issues. In other words, it is a way to express one's opinion, and also it has the power to influence the readers' thoughts towards some realities happening in society.

In this research, political cartoons deal with the relationship between visual and verbal signs of these cartoons because it will be helpful for the researchers to know about events depicted in these cartoons. Critical discourse analysis in part related to text study and conceptual frameworks is useful in breaking down the significance of political cartoon (Wisudawati, 2018). The reserachers focus on analyzing Anies Baswedan's cartoon that presents the 100 days as Jakarta governor because it is believed that the 100 days of work as governor is the proper time to observe about the beginning of government to be successful or not. Indeed, it cannot be made a definite measure, but at the moment of 100 days, it usually can be used to indicate the progress. In these cartoons, there are many signs that we get. Those signs show and give information to the readers.

In order to build an interpretation of political cartoons from the news portal, the writer finds some matters that can be analyzed by using the semiotic approach. Terminologically, semiotics is from Greek "semelon" that refers to sign (Nugraha, 2019), or in other words, knowledge deals with signs that have proposed to find the interpretation or description of it. According to Dumas (2016), any sign can signify anything. A sign includes both physical existing and non-existing objects as long as the objects have meanings. 
Furthermore, Eco (2018) states that semiotics is concerned with everything that can be taken as a sign. It means that semiotics deals with everything that stands for something else.

By conducting this study, the researchers expect to enrich knowledge about Semiotics theory applied in this political cartoon and also uncover the meanings of every sign found in the political cartoons. Thus, this study uses a Semiotic approach for understanding how signs, images, and the other elements become meaningful. The researchers also expect that the analysis of signs in the political cartoon can help deliver information for the readers following Anies' government, and give indication as to the progress of Anies' programs at his first 100 days work as Jakarta's governor. Therefore, the researchers are interested in conducting the research entitled A Semiotic Analysis of Political Cartoons on The First 100 Days of Anies Baswedan Government.

Researchers have paid some attention to investigate the cartoon and images from semiotics perspectives. Ulubeyli et al. (2015) study focused on analyzing signs in semiotic on political cartoons about accupational health and safety issues, which signify certain meanings. This study used a qualitative approach to describe the phenomena in clear and systematic ways. He used theory from Barthes to find out the denotative and connotative of signs employed in the cartoons. The sign can be related to the meaning of social-cultural and social convention. He also tries to improve meaning analysis with persuasive theory to find out the drawing style and relation with its sign meaning can also be understood.

The second study entitled "A Semiotic Analysis on the Logos of Three Cafes in Malang", a qualitative research by Firmansyah (2015). In the process of conducting the analysis, he figured out the meaning of the sign and also related to the concept and goals of the cafe. The study used Pierce's theory to analyze the icon, index, and also symbol of each cafe. For example, in analyzing Uno Cafe, the study attempted to figure out the sign using Pierce's system. Moreover, the study found the connotation of each logo and tried to relate it with the concept and goals of the cafe. The results revealed that every aspect of the logos represents characteristics and relation between the sign connotation of the logo and history, concept, and goal of the cafe through their symbolic in their name. Hence, the logo of the cafe is not merely for show, but also it demonstrates certain meanings.

From those two previous studies, the researchers found some similarities and differences between this present study and those previous studies. Firstly, compared to the research conducted by Ulubeyli et al. (2015), the object of this study is different. He analyzed signs in semiotic on political cartoons about accupational health and safety issues. In contrast, the object of this study is a political cartoon of Jakarta's Governor Anies Baswedan and focuses on analyzing the first 100 days of his government. The previous study focused on figuring out the connotative meaning, and he also tried to find the persuasive techniques used in drawing and find its relation to the meaning of the sign itself. 
Hasanah, N., \& Hidayat, D.N. (2020). A semiotic analysis of political cartoons on the first 100 days of Anies Baswedan government. EduLite: Journal of English Education, Literature, and Culture, 5 (2), 322333. DOI: http://dx.doi.org/10.30659/e.5.2.322-333

Furthermore, the research of this study is concentrated in analyzing the sign and interpreting the political cartoon based on the icon, symbol, and index in this cartoon using Pierce's theory. Secondly, compared to the research conducted by Firmansyah (2015), the object of this study is also different. He used three logos of each cafe, while the object of this study is political cartoons. He also tries to analyze the meaning of color, which appears in three logos of each cafe. However, the present study focuses on the identification of signs and the interpretation of cartoons because the researchers believe the result of the interpretation of cartoons can give clues more clearly to deliver information or a message.

\section{Semiotic}

Semiotics is one of linguistics branches which can be used to analyze an element of language in order to deliver its message or meaning. The name 'semiotics' is derived from the Greek word 'semelon' which means "sign". "Meaning" is always the result of social conventions, even when we think that something is natural or characteristic. In other words, Semiotics is the study of signs. Moreover, Forceville and van de Laar (2019) say that semiotics is the formal doctrine of a sign, which is closely related to logic.

According to all the definitions explained by Semioticians above, the researchers conclude that semiotics is a study of sign in the broader term of meaning. Semiotics has a close relation with signs aimed to interpret and understand the hidden meaning of signs. It can be a form of a picture, sound, photograph, and so forth. Thus, semiotics is very useful to understand the meaning of a sign, which is interpreted as something that can stand for something else, and also, we create our interpretation for analyzing signs.

\section{Sign}

Sign is a part of our life, signs can be words, texts, images, and objects. A sign includes both physical existing and non-existing objects as long as the objects have meanings. The sign cannot be called as a 'sign' if that thing does not have meaning. According to (Pierce, 1951), signs take the form of words, images, sound, odors, flavors, acts, or objects, but such things have no intrinsic meaning and become signs only when we invest them with meaning. A sign is also known as a combination of a signifier with a particular signified.

Saussure and Pierce created two dominant models of sign. According to Saussure (1967), cited in Chandler (2017), a sign as being composed of a signifier (significant) and a signified (signify). The signifier is the form that the sign takes, and the signified is the concept to which it refers (Saussure, cited in Chandler, 2017). Furthermore, according to Pierce (1951), cited in Chandler (2017), a sign ". . . [in the form of representamen] is something which stands for somebody in some respect or capacity (p. 250)". It addresses somebody, that it created in the mind of that person an equivalent sign, or perhaps a more developed sign. Therefore, Pierce's opinion explains how a sign created by the people's minds and also, they create sign themselves.

\section{Political Cartoon}

Nowadays, there are some kinds of cartoons that we can notice. According to Pierce (1951), some different types of cartoons are as follows: First, Comic Strips: Comic strips or funny cartoons is essentially a humorous book of the 
lives of the characters that occupy them. Comic strips frequently mirror the simple truth about our own lives in their perceptions and bits of knowledge into our general surroundings. Comic strips have the most prolonged proceeding with a run of prevalence among cartooning kinds, to a great extent, since individuals like to follow their preferred characters. Second, Editorial Cartoons: Editorial cartoons are a common form of cartooning, and often very contentious. Editorial cartoons are simply cartoons written to express a political or social perspective. They also first appeared on the scene at around the same time as the new newspaper had grown in popularity. Third, Gag Cartoon: Gag cartoons have become popular gag cartoon categories that might appear similar to comic strips. However, they are quite different. Except for comic strips, most gag strips have no standard collection of plot characters, and thus are typically human-paneled. Every new cartoon is a brand spanking new visual joke or gag provided in a single frame or box. Last, Web Cartoon: The web cartoon that can only be viewed by the Website cartoonist is produced on the internet. There is a vast sea of famous webcomics on the Internet. They are done by both amateurs and professionals, who profit from the right to publish everything on the Internet. The more innovative creators of webcomics exhibit their elements in full color, instead of using animation.

\section{METHOD}

The present study employed a qualitative research approach, and the content or document analysis as the research design. Qualitative studies are concerned with the principles of people's life configurations to issues (Saptanto $\&$ Dewi, 2020). Related to qualitative research, Glaser and Strauss (2017) stated that there are a great number of possible methods in dealing with qualitative research, such as case studies, document analysis, phenomenological studies, ethnography, or grounded theory research. He also explains that qualitative may use written documents. The term documents here refer to wide range or written, physical and visual materials. Documents may be personal such as files, reports, memoranda, or minutes or documents of popular culture, such as books, films, and videos. The writer conducted this study used document analysis method because it related to interpretation and description of semiotics in the political cartoon on the first 100 days of Anies' government.

In this research, the researchers collected and analyzed the data dealing with the relationship between the utterances and Anies' cartoons on the first 100 days as Jakarta's governor through some pictures collected through the internet that provided Indonesian political cartoons. To analyze the data, the researchers used some steps: first, categorizing the sign into the icon, symbol, index using typology of signs suggested by Pierce (1951) in order to identify kinds of sign in visual and verbal elements found in those cartoons; second, interpreting the meaning of the political cartoons based on Pierce's theory which employed in cartoons; last, drawing conclusion based on the result of the analysis. 
Hasanah, N., \& Hidayat, D.N. (2020). A semiotic analysis of political cartoons on the first 100 days of Anies Baswedan government. EduLite: Journal of English Education, Literature, and Culture, 5 (2), 322-

\section{RESULTS AND DISCUSSION Results}

1. Analysis of Political Cartoon 1

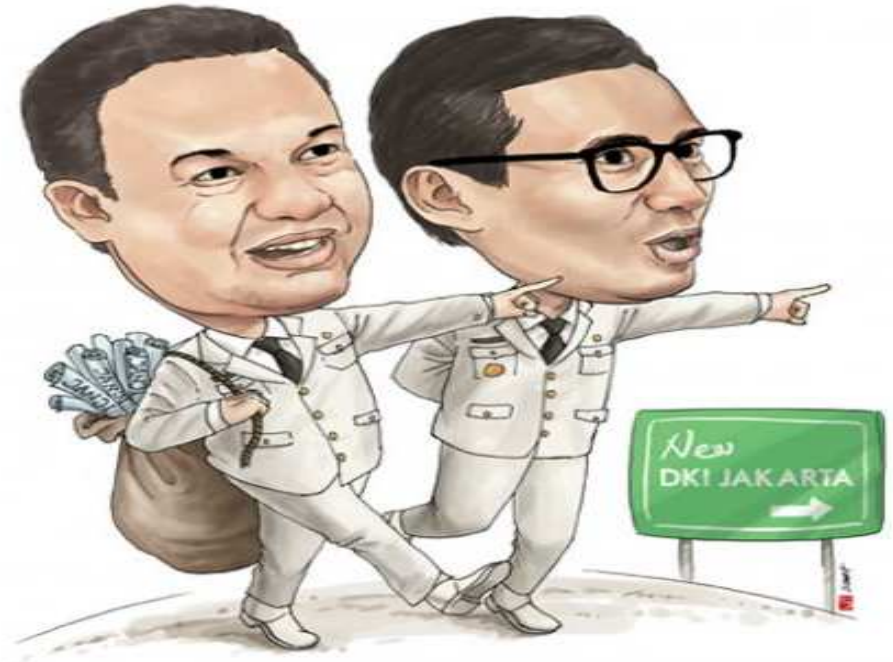

Figure 1. Cartoon 1

(source: Mediaindonesia.com)

This political cartoon was published on October 18th, 2017. It tells about Anies Baswedan since elected as Jakarta's governor. In this political cartoon, there are iconic signs that have symbolic meanings. It was visualized from the icon of Anies and Sandiaga, pointing to the future while Anies brings "promises" on his back. Furthermore, this cartoon intended to remind Anies of his promises to the new DKI Jakarta.

Table 1.

Classification of first political cartoon based on Pierce's model of sign

\begin{tabular}{llll}
\hline No. & \multicolumn{1}{c}{ Representamen } & \multicolumn{1}{c}{ Object } & \multicolumn{1}{c}{ Interpretant } \\
\hline 1. & Men wearing a uniform. & Anies Baswedan & New governor of Jakarta. \\
\hline 2. & $\begin{array}{l}\text { Papers with some "promises" } \\
\text { written on it. }\end{array}$ & Anies' bag & $\begin{array}{l}\text { Anies is ready to execute his } \\
\text { promises. }\end{array}$ \\
\hline 3. & $\begin{array}{l}\text { Board with New DKI JAKARTA } \\
\text { written on it. }\end{array}$ & A board & $\begin{array}{l}\text { Jakarta is running on the } \\
\text { new movement and new } \\
\text { governor. }\end{array}$ \\
\hline 4. & Green board & A board & $\begin{array}{l}\text { It tells that it is a board } \\
\text { usually used as a sign in } \\
\text { Jakartas highway. }\end{array}$ \\
\hline
\end{tabular}


EduLite Journal of English Education, Literature, and Culture

Vol. 5, No. 2, August 2020, pp. 322-333

\section{Analysis of Political Cartoon 2}

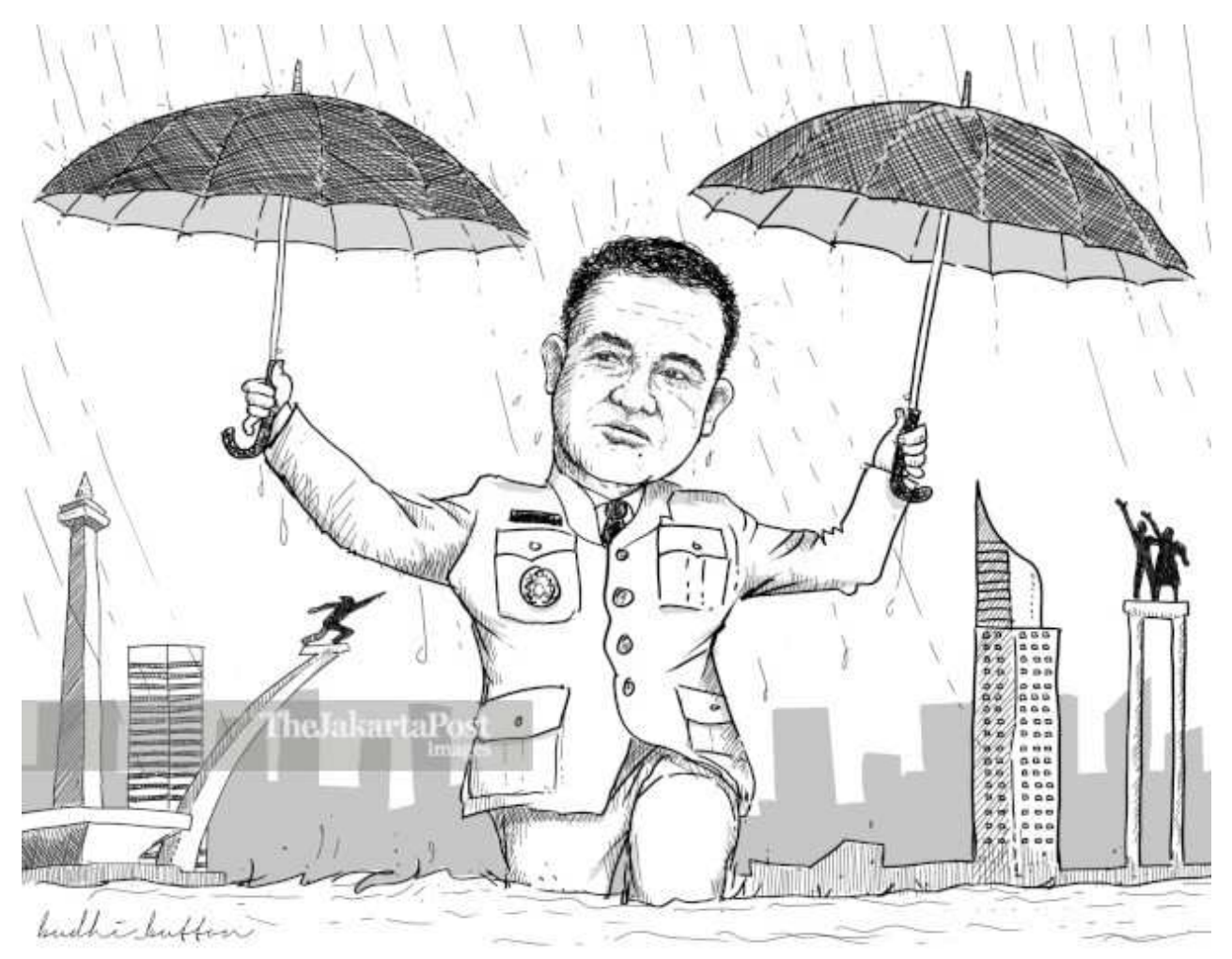

Figure 2. Cartoon 2

(source: The Jakarta post images by Budhi Button)

This political cartoon was published on December 19th, 2017. It tells about some of Anies' programs for the Jakarta's flood. Since Anies becomes the Jakarta's governor keeps running some programs although some people out there ignore his programs.

Table 2.

Classification of second political cartoon based on Pierce's model of sign

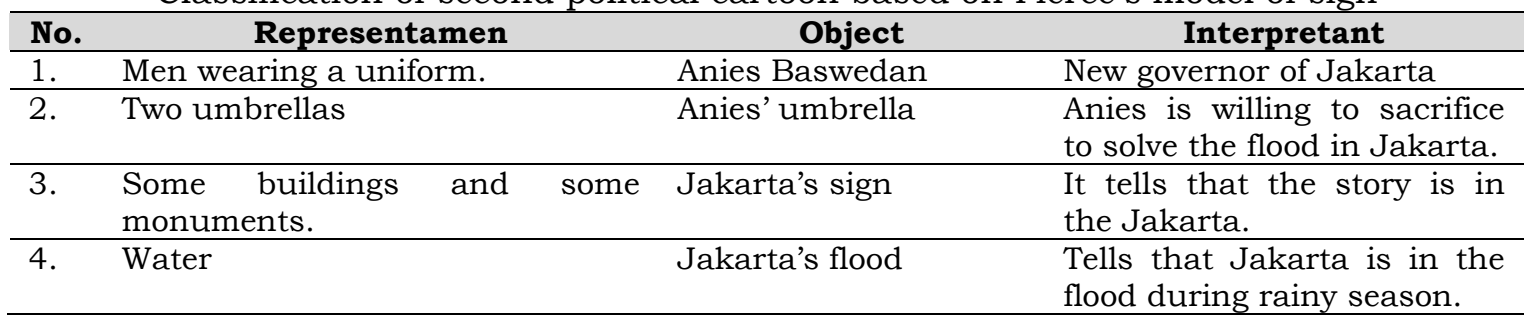


Hasanah, N., \& Hidayat, D.N. (2020). A semiotic analysis of political cartoons on the first 100 days of Anies Baswedan government. EduLite: Journal of English Education, Literature, and Culture, 5 (2), 322333. DOI: http://dx.doi.org/10.30659/e.5.2.322-333

\section{Analysis of Political Cartoon 3}

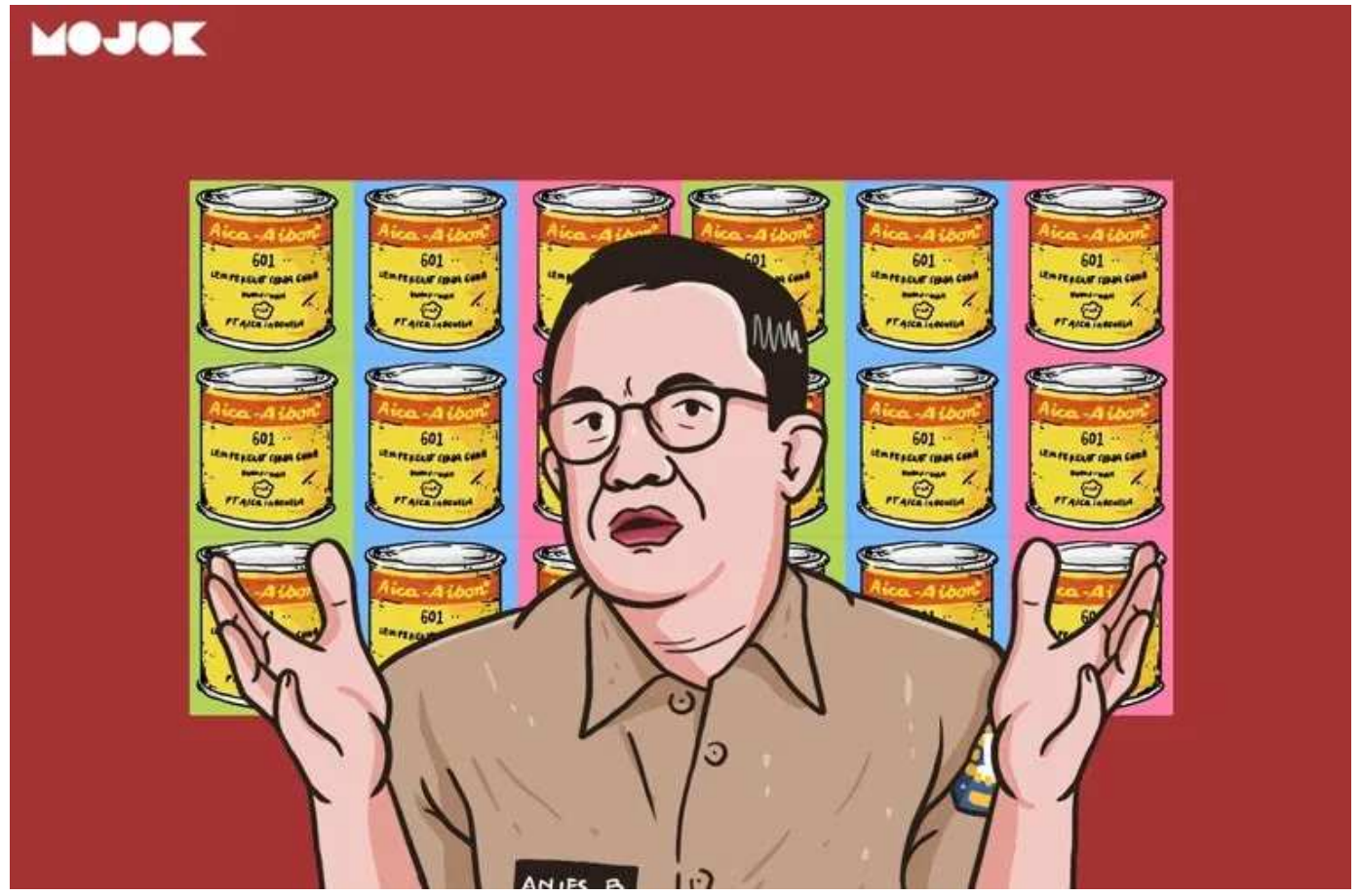

Figure 3. Cartoon 3

(source:Mojok.co)

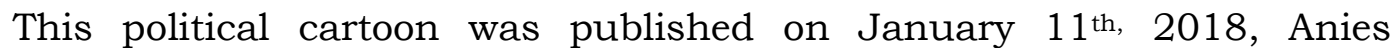
Baswedan's analogy indeed often appears to explain something. The plain water analogy was actually an affirmation of the analogy when Anies was attacked about the use of the reclamation island, the construction of the JPO, to waste management on August 13, 2018, at the Indonesia Lawyers Club (ILC). "Something that we usually face in Jakarta is like this plain water," Anies said while showing a glass of water. "But, when I said "this is plain water' 20 people in this room agreed to say 'this is soda' and those 20 people hold a microphone, so all people believe that this is soda," Anies said. "So, the way I answer is not to pick another microphone. I answered, 'give me time, and I will prove that this is plain water, not soda," the former Minister of Education said (redaksimojok.co, 2018).

Table 3.

Classification of third political cartoon based on Pierce's model of sign

\begin{tabular}{llll}
\hline No. & \multicolumn{1}{c}{ Representamen } & \multicolumn{1}{c}{ Object } & \multicolumn{1}{c}{ Interpretant } \\
\hline 1. & Men wearing a uniform. & Anies Baswedan & Governor of Jakarta \\
\hline 2. & 18 cans behind Anies. & Aibon glues & $\begin{array}{l}\text { Anies would rather be silent } \\
\text { than speak. }\end{array}$ \\
\hline 3. & Red background. & Anies' anger & $\begin{array}{l}\text { It tells that Anies prefer to } \\
\text { bury his anger inside him by } \\
\text { showing his substantiation. }\end{array}$ \\
\hline 4. & Anies' hands lift up & Anies' body language & $\begin{array}{l}\text { Tells that Anies not speak } \\
\text { by his mouth but action. }\end{array}$ \\
\hline
\end{tabular}




\section{Discussions}

In this part, there is an analysis of the interpretation of three Anies Baswedan's political cartoons as a governor above. The writer found three political cartoons of his first 100 days as governor; each cartoon is taken based on the period of the first 100 days during his time as governor of Jakarta, and the picture is taken based on the time of the month for 100 days. The interpretation of the image will be explained below.

In April 2010, the Foresight magazine released a special report entitled 20 persons 20 years, and Anies was included in the lists (Emerson \& Movchan, 2016). The first political cartoon of Anies Baswedan, in general, was seen that he was wearing a uniform and walking with his deputy governor, $\mathrm{Mr}$. Sandiaga Uno, carrying a bag in the form of a sack on his back and containing some paper inside. Then it was added to the gesture of Mr. Sandiaga Uno, who was pointing towards the front. Then what is the meaning of the signs that have been described? According to (Maroules \& Smelser, 2006), any sign can signify anything. This first picture was taken on October 18, 2017, where Anies Baswedan had just been elected and appointed as the Governor of Jakarta with Sandiaga Uno. The picture shows Anies was carrying some paper in her bag containing the word "promise," indicating that he was elected as governor that he brought some promises and be prepared to fulfill them. Then, the picture of them walking while pointing towards the front interpreted that his walk as the new governor would bring a new and more advanced Jakarta supported by a green board beside him and also read "new Jakarta". In general, the first political cartoon picture illustrates that Anies will soon carry out his duties as the new governor in Jakarta and hopes to build a new Jakarta with the promises he brings.

One of the causes of flooding is the land lower than the water BNPB (2019). The interpretation of the second political cartoon, in general, shows that Anies is in the middle of Jakarta while carrying two umbrellas to protect himself and Jakarta with an umbrella only enough for two people from the heavy rain and causes floods in Jakarta. In this picture, it is seen in the city of Jakarta because it can be shown from a picture of the National Monument, Pancoran Statue, and Welcome Statue as the symbol of Jakarta. In the picture, Anies brought two umbrellas to protect Jakarta from the rain, meaning that he was trying to carry out her program to protect and prevent Jakarta from flooding. The flood in Jakarta is shown by the presence of puddles in the picture when it rains. Furthermore, two umbrellas with a bigger Jakarta mean that Anies' program that he is running is not too deep, but Anies is still trying to protect Jakarta from flooding.

In this world there are some types of the country, talk less and do more like in Japan. Talk more and do more like in the US, yet different from Indonesia is talk more do less (Gus Dur, 2014, cited in Detik News). The third political cartoon was taken from mojok.co (2018) entitled "Anies with the glue mouth" supported by the number of pictures of glue behind Anies' governor. It can be interpreted that Anies pretended to be silent when there was a problem. The picture also explained the reason Anies prefers not to talk in response to the problem. He thinks if he talks, a lot more people will refute him and more talks to the negative realm. Then, he prefers to be quiet and show with proof of work rather than having to talk more to the public. 
Hasanah, N., \& Hidayat, D.N. (2020). A semiotic analysis of political cartoons on the first 100 days of Anies Baswedan government. EduLite: Journal of English Education, Literature, and Culture, 5 (2), 322333. DOI: http://dx.doi.org/10.30659/e.5.2.322-333

Basically, the elements employed in those cartoons consist of two different elements, which are visual and verbal elements. The verbal elements are in the form of words or phrases and dialogues, while visual elements are in the form of cartoons. Both the visual and verbal elements are dependent on each other. Those signs are used to deliver information.

Concerning language teaching, cartoons can be potential media. The use of cartoons in language teaching will help the students fully engaged between texts and exercises as well as learning about events happening in the world (Vincent, 2011). Also, cartoons will help students formerly to be more updated with the latest news and think more critically about the situation around them or the latest news. They try to digest and combine what they think and see in the political cartoons. Therefore, they can use cartoons to practice using speaking skills by expressing their thoughts and criticism through the political cartoons serving as the teaching media.

However, employing political cartoons in the class is challenging because we need skills in analyzing and understanding the words or the pictures provided. Hence, we need the students to do so, which not all students are necessary to do that. Nevertheless, for doing so, the students might enhance their skill of reading and analyzing by using their ESL or EFL critically. The students will engage their responses easily through reading visual texts because the students will easily relate the political cartoon provided with the real situation (Arizpe et al., 2014).

\section{CONCLUSION}

This study revealed the signs in the political cartoon at the first 100 days of Anies as governor. It used the theory proposed by (Pierce, 1951) typology of sign to analyze icon, index, and symbol. After analyzing the signs employed in political cartoons, then the researchers interpreted the signs based on the signs that found. Furthermore, in building the interpretation of signs, it is important to relate all the signs in the political cartoon. The interpretation appears when we relate the sign to each other. Besides, to obtain the deeper meaning of the political cartoon, the signs are also connected to the reality happening in society. The study that the signs in those political cartoons have powerful meanings to convey the aspiration of Indonesian people towards Anies' government.

The researchers expect this study will help and support the future researchers who are interested in analyzing and interpreting signs by using semiotic theory. The researchers also suggest finding other objects for analysis, such as advertisements, movie posters, or use a different form of a cartoon, such as comic strips or gag cartoons as the object of study. The next researchers who are interested in analyzing the meaning of political cartoons can use a different approach, such as syntagmatic relations (Chandler, 2017). A syntagmatic relation is the various ways in which elements within the same text may relate to each other. Facing some difficultness are not only found in the way of applying political cartoon in the classroom, but also in doing and analyzing the research. When doing this type of research, vast reading is crucial to enrich and support the content development of writing. Researchers should always think critically and be familiar with the latest situation or news 
as research about a political cartoon and a political figure is sometimes difficult to predict and interpret.

\section{REFERENCES}

Arizpe, E., Bagelman, C., Devlin, A. M., Farrell, M., \& McAdam, J. E. (2014). Visualizing intercultural literacy: engaging critically with diversity and migration in the classroom through an image-based approach. Language and Intercultural

Communication. https://doi.org/10.1080/14708477.2014.903056

Chandler, D. (2017). Semiotic The Basic - Third Edition. In Routledge, Taylor \& Francis Group.

Dumas, M. J. (2016). Against the Dark: Antiblackness in Education Policy and Discourse. Theory into Practice. https://doi.org/10.1080/00405841.2016.1116852

Eco, U. (2018). Semiotics and the Philosophy of Language. In Reading Eco. https://doi.org/10.2307/j.ctt1zxz0xk.6

Emerson, M., \& Movchan, V. (2016). Deepening EU-Ukrainian Relations: What, why and how? In A Trilogy of Handbooks: Understanding the EU's Association Agreements and Deep and Comprehensive Free Trade Areas (DCFTAs) with Georgia, Moldova and Ukraine.

Firmansyah, A. (2015). A Semiotic Analysis on the Logos of Three Cafes in Malang [Universitas Brawijaya]. http://jimbastrafib.studentjournal.ub.ac.id/index.php/jimbastrafib/arti cle/viewFile/947/855

Forceville, C., \& van de Laar, N. (2019). Metaphors portraying right-wing politician Geert Wilders in Dutch political cartoons. In Populist Discourse: Critical Approaches to Contemporary Politics. https://doi.org/10.4324/9780429026751-18

Glaser, B. G., \& Strauss, A. L. (2017). Discovery of grounded theory: Strategies for qualitative research. In Discovery of Grounded Theory: Strategies for Qualitative Research. https://doi.org/10.4324/9780203793206

Marin-Arrese, J. I. (2019). Political cartoon discourse: Creativity, critique and persuasion. Cultura, Lenguaje $y$ Representacion. https:// doi.org/10.6035/CLR.2019.22.7

Maroules, N., \& Smelser, N. J. (2006). Seeing Sociologically: The Routine Grounds of Social Action. Contemporary Sociology: A Journal of Reviews. https:// doi.org/10.1177/009430610603500552

Mondry, H. (2017). A conversation on the politics of (Un-)natural substances: Ingesting psychoactive matter in 19th century Russian literature and culture. In Zeitschrift fur Slavische Philologie.

Nugraha, D. N. S. (2019). The Color Meaning in Go Green Logo: A Semiotics Study. Global Business and Management Research. 
Hasanah, N., \& Hidayat, D.N. (2020). A semiotic analysis of political cartoons on the first 100 days of Anies Baswedan government. EduLite: Journal of English Education, Literature, and Culture, 5 (2), 322-

Pierce, J. R. (1951). Communication theory. Physics Today. https://doi.org/10.1063/1.3067249

Richmond, V. P., \& McCroskey, J. C. (2019). Human communication theory and research: Traditions and models. In An Integrated Approach to Communication Theory and Research, Third Edition. https://doi.org/10.4324/9780203710753-21

Saptanto, D. D., \& Dewi, M. K. (2020). Gundala and Gatotkaca in the concept of modern Indonesian superheroes: Comparative analysis of the Indonesian and American superheroes. EduLite: Journal of English Education, Literature and Culture. https://doi.org/10.30659/e.5.1.136147

Ulubeyli, S., Arslan, V., \& Kivrak, S. (2015). A semiotic analysis of cartoons about occupational health and safety issues in the construction workplace. Construction Management and Economics. https://doi.org/10.1080/01446193.2015.1024270

Vincent, C. (2011). The use of political cartoons in the EFL/ESL classroom: Learning English and enhancing critical thinking in the context of Saudi $\begin{array}{llll}\text { Arabia. } M A & \text { TESOL, }\end{array}$ https://digitalcollections.sit.edu/ipp_collection/504/

Wisudawati, A. F. (2018). No Title. Edulite Journal of English Education, Literature and Culture, 3(2), 149-160.

http://dx.doi.org/10.30659/e.3.2.149-160. 